"Why public education is unequal: case of Ukrainian rural schools"

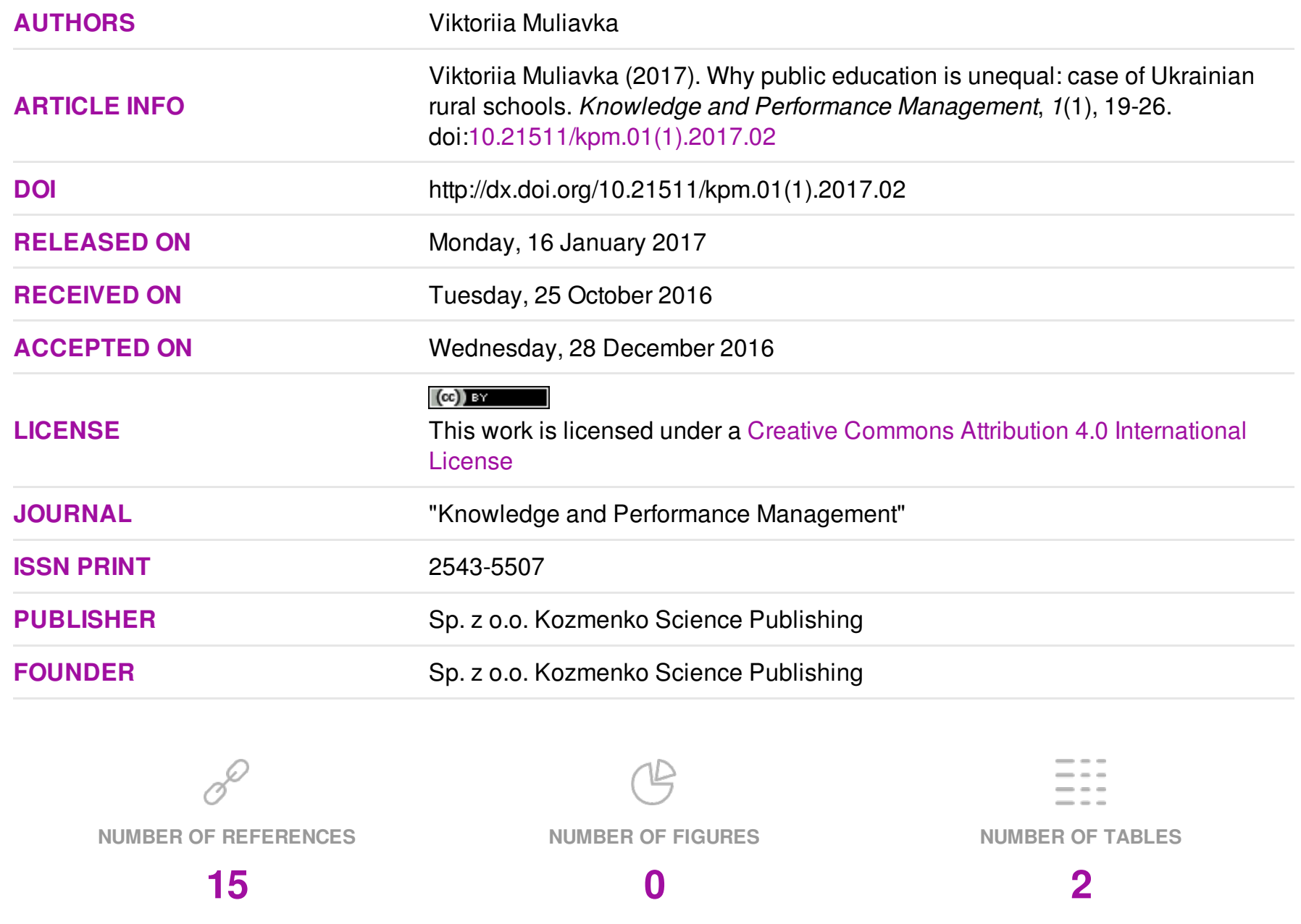

(C) The author(s) 2022. This publication is an open access article. 
Viktoriia Muliavka (Poland)

\title{
Why public education is unequal: case of Ukrainian rural schools
}

\begin{abstract}
Ukrainian educational system is not able to provide equal access to the university, regardless of children's socio-economic background. Despite of the anti-discrimination ideas in legislation and in public discourse (with implementation of transparent mechanism of selection in 2004 - External Independent Testing), there are statistically significant differences in the results of EIT (that defines chances to get higher education) between children from rural area and their peers from urban schools (especially from elite ones). The research is based on Bourdieu's theoretical concept of capitals and seven in-depth interviews with teachers from rural schools in different regions of Ukraine. Based on the findings, the author divides mechanisms of reproduction of educational inequality into four dimensions: economic capital of the school, economic capital of the family, cultural capital of the school and cultural capital of the family. Current educational reforms of secondary and higher education in Ukraine will not improve situation with access to higher education for children from poor social background. Closing of unprofitable universities and schools in rural area, expending the years of studying at school and implementation on funding reallocation based on a competition with financial support only of those, who are more successful, will deepen educational inequality, making accesses to the mechanism of improving socio-economic position even more dependent from socioeconomic background.
\end{abstract}

Keywords: educational inequality, education policy, economic capital, cultural capital.

JEL Classification: I24, O15.

Received on: $25^{\text {th }}$ of October, 2016.

Accepted on: $28^{\text {th }}$ of December, 2016.

\section{Introduction}

Current educational policy in Ukraine becomes more and more oriented on transformation of higher education system based on the Anglo-American liberal model: closing of non-profitable schools and universities, widening of private expenditures on education and stimulation of competition between educational institutions and among students for public financial support. However, reformers do not take into account substantial structural differences in the ability to pay for private services between Ukrainian and Western societies. Implementation of such reforms in Ukrainian context will lead to the deepening of educational inequality.

Despite the common misconception that free higher education in Ukraine provides equal access for youngsters from different social backgrounds, statistics shows that youth from rural areas perform worse in External Independent Testing ${ }^{1}$ than their peers from urban elite schools by more than 10 points (out of 200), and that significantly reduces their chances to get higher education and improve their socio-economic positions in a social structure (Table 1). In particular,

(C) Viktoriia Muliavka, 2017.

Viktoriia Muliavka, Master student in Economy and Society at Graduate School for Social Research, Poland.

This is an Open Access article, distributed under the terms of the Creative Commons Attribution 4.0 International license, which permits unrestricted re-use, distribution, and reproduction in any medium, provided the original work is properly cited.

1 External Independent Testing - school-leaving examinations for admission to universities in Ukraine. due to the research of Ukrainian rural schools, the main reason of young people's from villages fewer chances to prepare themselves to enter university is the lack of cultural and economic capital (Muliavka, 2015).

Table 1. Average score of External Independent Testing results by type of school ${ }^{2}$ and place of residence (2014)

\begin{tabular}{|l|c|c|c|c|}
\hline \multicolumn{1}{|c|}{$\begin{array}{c}\text { Place of } \\
\text { residence }\end{array}$} & $\begin{array}{c}\text { Ordinary } \\
\text { school }\end{array}$ & Lyceum & Gymnasium & $\begin{array}{c}\text { Specialized } \\
\text { school }\end{array}$ \\
\hline Kyiv & 150.260 & 165.736 & 166.067 & 158.789 \\
\hline Region center & 150.523 & 163.704 & 159.989 & 158.865 \\
\hline City & 151.134 & 159.301 & 157.517 & 156.560 \\
\hline $\begin{array}{l}\text { Urban-type } \\
\text { settlement }\end{array}$ & 148.716 & - & - & - \\
\hline Village & 146.059 & - & - & - \\
\hline
\end{tabular}

Quantitatively calculated differences in access to higher education for youth with different social background requires in-depth qualitative studying in order to understand how the mechanisms of reproduction of educational inequality work. Based on the in-depth interview with teachers from rural schools and theoretical concept of cultural and economic capital (Bourdieu, 1979; Bourdieu, 1998), the research aims to describe the mechanisms of reproduction of educational inequality in Ukrainian context and problematize possible social consequences of current neoliberal reforms for youngsters from rural area, one of the most vulnerable category of Ukrainian society.

\footnotetext{
2 In Ukrainian system of secondary education, there are ordinary schools, widespread in rural area, and elite schools (lyceums, gymnasiums and specialized schools) that are characterized by in-depth learning of specific subjects, are available only in urban area and sometimes require to pay some tax.
} 


\section{Theoretical and methodological approach}

In order to study deeper structural factors of educational inequality in Ukrainian society and identify mechanisms of its reproduction, the method of indepth semi-structured interviews with teachers of Ukrainian language and literature was adopted, as Independent Testing in those subjects is obligatory for all university applicants.

The sample was formed from schools that had the lowest average scores of Independent Testing in 2013 and 2014 (lower than 124 that is minimum score to apply to the institution of higher education). Of the 12 selected schools, all were rural, located in various regions of Ukraine. 7 schools out of 12 were selected as objects of research (Table 2), considering the infrastructural problems of transport links, lack of contact with the school administration, occupied status of Donetsk and Lugansk regions. All interviews were organized in the period 01.09.2014-01.12.2014.

Table 2. General information about schools

\begin{tabular}{|c|c|c|c|}
\hline № & Name of the school & Location & Average score of Independent Testing \\
\hline 1 & $\begin{array}{l}\text { Koblivska secondary school levels I- } \\
\text { III }\end{array}$ & $\begin{array}{c}\text { Mykolaiv region, Berezanskii district, } \\
\text { village Kobleve }\end{array}$ & 119.3 \\
\hline 2 & $\begin{array}{l}\text { Sayivska secondary school levels I- } \\
\text { III }\end{array}$ & $\begin{array}{c}\text { Dnipropetrovsk region, Pyatykhatky district, } \\
\text { village Sayivka }\end{array}$ & 114.3 \\
\hline 3 & $\begin{array}{l}\text { Staroosotska secondary school } \\
\text { levels I-III }\end{array}$ & $\begin{array}{l}\text { Kirovohrad region, Olexandrivsky district, } \\
\text { village Stara Osota }\end{array}$ & 118.8 \\
\hline 4 & $\begin{array}{l}\text { Khorlivska secondary school levels I- } \\
\text { III }\end{array}$ & $\begin{array}{c}\text { Kherson region, Kalanchak district, } \\
\text { village Khorly }\end{array}$ & 114.8 \\
\hline 5 & $\begin{array}{l}\text { Verhivska secondary school levels I- } \\
\text { III }\end{array}$ & $\begin{array}{c}\text { Vinnytsia region, Trostyanetsky district, } \\
\text { village Verhivka }\end{array}$ & 112.5 \\
\hline 6 & $\begin{array}{l}\text { Zarubynets'ka secondary school } \\
\text { levels I-III }\end{array}$ & $\begin{array}{c}\text { Zhytomyr region, Andrushevsky district, } \\
\text { village Zarubyntsi }\end{array}$ & 118.8 \\
\hline 7 & $\begin{array}{l}\text { Hnylychanska secondary school } \\
\text { levels I-III }\end{array}$ & $\begin{array}{l}\text { Kharkiv region, Velikoburlutsky district, } \\
\text { village Hnylycia }\end{array}$ & 119.1 \\
\hline
\end{tabular}

The theoretical approach of the research is based on the concept of economic and cultural capital of Pierre Bourdieu. Economic capital, according to Bourdieu, is "directly and immediately converted into money and institutionalized in the form of ownership" (1979). Describing the specifics of reproduction of inequality in education, Pierre Bourdieu drew it less attention than the cultural capital. Nevertheless, he states: "The dominant fractions, which tend to give more importance to investment in education within the overall strategy of asset diversification and investments designed to combine safety with high returns, have lots of ways to avoid scholastic verdicts. Direct transfer of economic capital is one of the main means of reproduction". What is more, in Ukrainian context, economic capital plays more important role because of the poorer socio-economic conditions comparing to economically developed societies. Cultural capital, according to Bourdieu, has a direct link with the education system. This type of capital "may be institutionalized in the form of educational qualifications" (1979). In addition, according to his research of elite schools in France, namely different cultural elements of behavior, transmitted in the socialization of children from different classes, promote continuous reproduction of social inequality (Bourdieu, 1998).
According to the Pier Bourdieu's theoretical concept, factors of educational inequality in the rural area are grouped by their belonging to economic or cultural capital. Those two groups of factors are used as separate dimensions although this division is only analytical structure, since in real life economic and cultural capital are closely interrelated. Components of economic and cultural capital are analyzed within the family and school, as this two social institutions are the main sources, forming the field of competition between students during their preparation to Independent Testing and entering university. This approach is reflected in a number of previous works on educational inequality (Briginets, 2010; Devine, 2004; Reay, 1998; Svityaschuk, 2013). Structural factors of educational inequality are grouped into four dimensions: economic capital of the school; economic capital of the family; cultural capital of the school; cultural capital of the family.

\section{Economic capital}

Taking into account the differentiation of Ukraine's school network in terms of learning environment and the stratification of populations by access to resources, economic capital is an important factor that simultaneously generates and promotes the continuous reproduction of educational inequality. In turn, this affects the results of External Independent Testing (EIT), which defines children's chances to enter university. 
2.1. Economic capital of the school. According to the previous researches (Briginets, 2010; Devine, 2004; Reay, 1998; Svityaschuk, 2013), favorable learning conditions supported by economic capital include ensuring the proper state of schools' facilities and resources; a mechanism to fully and timely provide schools with necessary teaching materials; the availability of additional funding sources. Therefore, this paper offers some insight into the aspects of ensuring this kind of learning environment in schools with the lowest results of EIT, based on the results of the interviews with teachers from rural schools.

\subsubsection{Lack of a mechanism to fully and timely provide} schools with necessary teaching materials. The lack of proper teaching materials is one of the reason why children cannot master the necessary knowledge basis, as the materials chosen by teachers themselves may not always fit the state's educational standards: "For the last two years, I never had the required amount of books. No amount of pleas to our local government was enough. Last year, we got several books on literature, but this year, I had to buy everything myself." (Saivka, Dnipropetrovska oblast).

2.1.2. The issue of ensuring the necessary facilities and resources for the schools by the state. The impact of this aspect on the success in passing EIT was found in a comparative study of ordinary and elite schools conducted by Brygynets and Grushetsky (2010). According to the interviews with teachers, the lack of funds in rural schools prevents the normal flow of the learning process, ranging from basic hygiene upkeep to implementation of information technology into the learning process: "The state does not provide our school even with the detergents and things like that, for the last two years. Although we don't have Internet connection in the computer class, the computers are ancient." (Khorly, Khersons'ka oblast). Thus, the differentiation of schools based on their facilities and resources creates inequality in the access of students of different schools to e-learning materials, which is also an important part of the educational process, especially given the lack of timely and full provision with books.

2.1.3. The lack of additional sources of income. The natural adaptive practice to the problems with ensuring appropriate learning conditions by the state is searching for alternative sources of income. Considering that the lack of budget funding is a common thing for Ukrainian schoolsystem, the parent committee ${ }^{1}$ takes the matter into their own hands, compensating for the lack of public

\footnotetext{
${ }^{1}$ Public institution that contributes to solving major issues of training and education of students and improve the material base of schools (it is not obligatory and is usually organized on the parent's initiative).
}

expenditures and directing the money precisely on what the school needs most. However, according to respondents, this practice is not common in rural areas: "My colleagues from other villages and exclassmates that work in urban schools tell me that parents are rather involved in the learning process, whereas parents of the children from my class don't go any further than renovating the classroom. They are not concerned about where I get the learning materials, or if I get them at all." (Verkhivka, Vinnyts'ka oblast).

Another source of funding is sponsorship; however, this material support in rural area traditionally has another purpose than supplying the learning materials: "Our proprietorship helps us as much as it can, mostly in terms of technical support. For example, it bought us a strimmer, and it mows the grass around the school from time to time." (Verkhivka, Vinnyts'ka oblast) Thus, the lack of additional funds only deepens the problem of ensuring the facilities and resources and supplying the required learning materials in rural areas. This, in turn, disrupts the provision of normal learning environment and makes the process of preparing to enter university for children from rural schools more difficult.

The situation with access to higher education for children from rural schools will become even worse after implementation of neoliberal school-reforms. According to the recommendations of International Monetary Fund (2015), small rural schools in Ukraine have to be closed because of the ineffective reallocation of public funding. New draft of the law on education states that the number of students in classes should be not less than 15 (the average amount for rural schools is 12.5). As an alternative, government proposes to create big regional schools (hub-schools) with good conditions and modern facilities. However, these schools will be no more than a new type of elite school (with the only difference in free transportation of children from rural areas), as at the initial stage of the reform, they will not provide places for all children from surrounding rural areas. Most of them will be pushed to go to the neighboring rural school by bus that can be quite problematic considering the lack of money on transportation in regional budgets. What is more, even for those children from rural area that will have a chance to study in better school environment, the reform will not solve the problem of the lack of cultural and economic capital of the family that causes reproduction of inequality in access to higher education. 
2.2. Economic capital of the family. Despite the fact that primary and secondary education is free in Ukraine, it is still dependent from the financial abilities of the parents. Economic capital of the family affects after-school learning, selection of the educational path and future educational institution in particular. Therefore, it is important to cover the specific features of this influence in schools with the lowest rates of EIT.

\subsubsection{Limited after-school learning opportunities.} Devine, in her study of American and British middle class called "Class practices. How parents help their children get good jobs", stresses that financial capacity and class membership of the parents influence the material assistance in education and additional training that are important factors of the reproduction of educational inequality (2004). Economic capital of the family in the context of Ukrainian society plays an equally important role as cultural capital, given the fact that EIT is a separate mechanism of assessment, and preparation to it is not provided within the ordinary school curriculum.

As interviews with teachers show, in rural areas, after-school learning opportunities are quite limited: "Not many children have tutors, only about threefour per grade. They also don't attend any training courses in universities. It might be connected with the fact that we are very far from universities, which means extra expenses for travelling. It is convenient for kids that live in cities; our children have no such opportunity, as their classes end at 3 o'clock, which leaves no time for getting to the training courses in big city." (Kobleve, Mykolaivs'ka oblast) Thus, limited financial resources and lack of additional funding for the preparation for EIT in rural area are also accompanied by the need to conquer long distances. Children who live in remote villages are deprived of the possibility to use the services of tutors and attending training courses in universities, and the objective outcome of it is the worse results of the Independent Testing.

2.2.2. Selection of the educational path. The problem of small number of students in rural schools is connected not only to demographical factors. Many children live school after nine grade in order to get vocational education. Connected with the lack of economic capital, such decision have rational reasons: firstly, it allows the child to receive a stipend, which helps the family budget; and, secondly, it makes possible faster entering the labor market, which also reduces household expenditures. The interviews show that rural teachers are cautious towards their students receiving higher education: "I always tell the kids in my class to not get their hopes up even if they pass EIT; they should still have money to pay for tuition in case they can't stay on the scholarship." (Khorly, Khersons'ka oblast).

Higher education is viewed as a financial risk in the rural area, which further complicates the preparation for EIT. In most cases, the family makes a decision to choose a less risky educational path, which involves less expenses - vocational education. As explained one of the respondents: "Parents of the kids that left after 9 grade told me that they need the stipend from the vocational school. And when I proposed the idea that a child should have a say in this, they just said: "We've already decided." (Saivka, Dnipropetrovsk oblast).

The situation when $50-60 \%$ of children leave school after finishing 9 grade is a distinctive feature of the rural area. Introduction of targeted approach in reallocation of stipends, due to which financial support will receive only limited amount of the most successful and the most deprived students (Ukrainian Cabinet of Ministers, 2016), is likely to contribute to the worsening of this situation, given that even such thing as the implementation of fees for textbooks could have strong negative consequences for rural schools. "If they introduce fees for textbooks, no one's going to stay for 10 grade. We already don't know if we'll have 10 grade, everyone but three kids has decided to leave. If nothing changes, they will all leave." (Verkhivka, Vinnyts'ka oblast). Ukrainian government should be more careful in reforming the higher education, as it might worsen the situation with already restricted access to higher education for rural school graduates. The decision to reduce the number of universities and lowering the chances of receiving a stipend (Kvit, 2015) could be an obstacle on the way to getting a degree for children from poor families, making higher education even more dependent on financial means.

2.2.3. Selection of an educational institution. Apart from the fact that the family's financial situation can influence the choice of the educational path of the child, it also influences the choice of the educational institution. Such widespread problem in rural areas as the lack of sustainable income makes people choose institutions with lower tuition fees, less competition and the ones closest to the place of residence over other available options. One of the teachers whose daughter is going to take EIT explained her logic in choosing the university: "This whole EIT thing is so stressful; they keep changing the rules, so now we have to sort the universities and faculties in priority order. We decided to apply to Kirovohrad State University and Vynnychenka. Even though we have connections in Kyiv, which means that accommodation would not have been a problem, it's too expensive to go back and forth." (Stara Osota, Kirovohrads'ka oblast). 
As the preparation to EIT is not sufficient in rural schools, graduates receive low scores on the test, which causes the children and their parents to choose less prestigious universities, and that, in turn, calling into question the further successful employment, even with the diploma of higher education. "In the last four years, only one of our students got into Kiev University. Mostly kids don't even try. They go for Mykolaiv or Odessa, because they are much closer, it's cheaper to go there, and there's a bigger chance of entering." (Kobleve, Mykolaivs'ka oblast).

Considering current economic crises, Ukrainian government is oriented on budget cuts on social sphere, including higher education that still is free for almost half of the students. What is more, Ministry of Education legitimizes stimulation of competition between universities in receiving public funding by following "European model" and improving the quality of education. In 2016, there was implemented performance-based system of funding reallocation, due to which more successful universities will receive more material support from the state. What is more, there is a practice of affiliation of small universities with bigger once. Such policy can improve only quantitative indicators of quality; however, stimulation of competition between educational institutions in the context of budget cuts will increase competition between students, in which children from rural area will be those who lose. As due to the new mechanism of funding reallocation "money follows student" more prestigious universities will allocate even more budget places, for applicants with poor social background it will lower the chance to take free education at list in a small region less prestigious institution.

\section{Cultural capital}

Apart from economic capital, a significant factor in reproduction of educational inequality is a cultural capital. While depending on the limited access to financial resources, it reveals a cognitive dimension based on a knowledge and ideas, widespread in rural area, which are an obstacle on the way of rural children getting a higher education.

3.1. Cultural capital of the school. Structural limitations of the rural area create reproducible cultural capital of the school, formed by such phenomena as limited preparation to EIT by the school curriculum, the outflow of more successful students and, as the result, perceiving the students with high educational performance as outliers.

3.1.1. Limited preparation to Independent Testing by the school curriculum. While using the results of EIT as a criterion for comparing the quality of education, it is important to note that the school's curriculum does not contain specific preparation for Independent Testing. EIT contains a list of tasks aimed to evaluate the knowledge gained throughout the learning process at school, but the state standard of basic and secondary education does not include generalization and systematization of the material learned during 11 years of studying (Cabinet of Ministers of Ukraine 2011). It is one of the reasons why youngsters from rural schools are worse prepared for Independent Testing than their peers from urban area. "Rural schools are worse in preparing kids to EIT than city schools. They (in urban area) have specialized classes, and we have only two hours a day dedicated to Ukrainian language, is that enough, though? Our curriculum does not include time for preparation, so it's teacher's' responsibility to find that time, but it's still not enough.” (Stara Osota, Kirovohrads'ka oblast).

Preparation for testing during the learning process is personal initiative of teachers. Specialized schools, located in urban areas, give an opportunity for in-depth studying of certain subjects that makes it possible to prepare for the EIT during educational process, whereas in rural areas there is no such an opportunity, as there is only one ordinary school in a village.

3.1.2. The outflow of more successful students. If in the urban area usually the weaker students decide to leave school after 9 grade, in villages, there is another reason of changing educational institution. One of the possibilities for rural children to study chosen subject more intense and to be better prepared for EIT is searching for educational institutions outside of their place of residence. "Smart kids usually leave our school for specialized schools in the nearest cities. For example, the smartest children from my class have left after 9 grade; one is studying in Kherson, the other is in Kyiv. So the strongest children almost always leave earlier." (Khorly, Khersons'ka oblast)

The process of leaving rural school in order to get better education in city shows structural problem of unequal relocation of resources between rural and urban area. Such mechanism of adaptation not only reproduces inequality in educational chances (as not all of parents have ability to provide their children with everyday transportation to urban school or moving to city in order to give their child better education), but also influences educational environment in rural school. As a teacher from rural school with individual training (2 students in a group) said, children do not see other students while studying individually, and it is demotivating for them. 
3.1.3. Perceiving of the students with high educational performance as outliers. As in the rural area studying conditions are worse because of the list of structural factors mentioned in this paper, there are usually a few students with high educational performance in a school and local teachers perceive them as outliers. The process of identifying these students also differs from urban area. A student is considered "excellent" if he or she has high grades in at least one of the subjects, which requires more efforts from other teachers to make a student excellent in their subjects as well. "The last excellent student we had was I don't even remember how long ago. I came to work here in 2005, and there was a boy in 10 grade who had straight A's. I thought I was going to go grey in those two years. As we know, people are usually good at either math, or languages. He was good at math, and I had to spend all my free time tutoring him (in languages) with having no experience at all." (Verkhivka, Vinnyts'ka oblast).

Teachers also associate the low level of knowledge of students with limited structural conditions in rural area. The number of students in a group suffers from the fact that the lack of normal employment leads to migration of able-bodied individuals with children to larger settlements, while vulnerable population usually stays in rural areas. "I have to say, kids themselves have changed. We live in a village, after all, which means many people move away. Those children that stayed are nice, but for some reason, they started neglecting their schoolwork. Yesterday's mediocre student was much stronger in academic sense than today's, more able to learn fast." (Zarubyntsi, Zhytomyrs'ka oblast).

The problem of leaving rural school before graduation will probably worsen because of one another important reason. As was mentioned before, the lack of economic resources is one of the factor that pushes children from rural area to choose vocational education and to live school after 9 grade. Following Western educational model, Ukrainian Ministry of Education is going to extend the years of studying in school from 11 to 12, starting from 2018. The reform can result in the situation when even children with poor social background whose parents do not have a possibility to move to the city will prefer vocational education in order to shorten the financial expenses of the family.

3.2. Cultural capital of the family. Apart from the school network, structural conditions of rural area also influence ideas of the individuals, who stay in these conditions during the process of socialization. In the context of reproduction of educational inequality, it is important to consider such characteristics of cultural capital of the family as the specifics of the perception of Independent Testing, limited parental involvement in education and time distribution of children.

\subsubsection{Specifics of the perception of Independent} Testing. First of all, it should be understood that urban residents, especially those living in big cities, are able to quickly adapt to changes (particularly in education). In rural areas, the process of innovation, its perception and internalization usually lasts longer. It is primarily connected to the issue of informational isolation and the lack of explanatory campaigns about EIT. If, in the cities, such information is more accessible due to the spread of the Internet, in rural areas, it is complicated by the fact that the amount of users of the global network among villagers is only $31 \%$ (Kyiv International Institute of Sociology, 2013).

Interviews with teachers from rural schools show that even despite the fact it has been 10 years since the implementation of EIT, the mechanism of entry to higher education is still making rural residents anxious, "parents are intimidated by tests for some reason", saying, "there is not enough information". (Verkhivka, Vinnyts'ka oblast) Comparing entrance exams ${ }^{1}$ internalized by the older generation as the only appropriate mechanism for admission to universities and current independent evaluation, several respondents said that the previous system was perceived by parents as more clear, while the lack of knowledge about testing causes fear and creates the illusion that the "test are already bought". This is another barrier for rural students on their way to getting into a university.

3.2.2. Limited parental involvement in education. Parent's involvement in the educational process and, consequently, the success of a child correlates closely with the sphere of employment of parents and their level of education. According to Oksamytna's research on intergenerational educational mobility, educational trajectory is reproducible (2006), as in order to efficiently help your child in school, you must have the respective cultural capital. By this dimension, the prospects of higher education for children from rural areas are also disappointing.

Talking about parents of her students, one of the teachers said: "Among the parents of my students there is not one person with a degree. There are some who didn't even graduate from high school, most of the moms are unemployed, some are even retired"

\footnotetext{
Before the implementation of EIT in 2014, there were separate entrance exams to each university.
} 
(Zarubyntsi, Zhytomyrs'ka oblast). Despite of the fact that many people in rural area are officially unemployed, it does not free up the time on children's education, as they don't consider such behavior as required, transferring all the responsibility of children's educational performance on teachers. As teachers say, parents are quite distant from school; barely any of them are interested in their child's progress. That also is the reason why parents do not save money for children's preparation for the EIT. According to the respondents, if graduates from their schools enter university, it is usually paid form of studying, as they have too low grades to compete for the tuition-free places with applicants from rural area. It tells about parent's misallocation of financial resources because of the lack of cultural, not economic capital, as preparation for EIT with tutors or on courses costs less than studying fee in university.

3.2.3. Time distribution of children. Limited employment options in rural area generate specific cultural capital of locals caused by the fact that housework is a significant part of the income of most rural households. This, in turn, affects the educational performance, creating institutional practices of involving children in the household work: "Sometimes it gets really hard, so kids volunteer to help. In autumn, we let children tend to their backyards during the lessons. Parents write inquires, as we are responsible for the kids during the schoolday, and children have to catch up later. We know that during this time kids are not just fooling around, skipping classes, but they help their parents to earn some extra money. They can come in later to have some additional lessons if they are too far behind. It's always been like this." (Hnylytsia, Kharkivs'ka oblast). Thus, limited involvement of parents in the educational process and practice of working on the farm is another aspect that makes it difficult to achieve success in education for students in rural schools: "Children could study better, but they lack time and support. If parents helped in the learning process, it would positively influence the academic progress." (Verkhivka, Vinnyts'ka oblast).

As the interviews with teachers from rural schools show, the problem of a lower quality of education in rural schools lies not only in financial constraints, it is rooted in much deeper structural problems that are difficult to change only with the mechanisms of educational policy. What is more, current educational policy of Ukrainian government not only won't solve the problem, but also will make access to higher education for children from rural area even more restricted.

\section{Conclusions}

As the research of the impact of the economic and cultural capital on educational inequality shows, Ukrainian educational system is not able to provide equal access to the university, regardless of children's social background. Despite the anti-discrimination ideas in legislation and in public discourse (with implementation of transparent mechanism of selection in 2004 - External Independent Testing), there are statistically significant differences in the results of EIT that define chances to get higher education between children from rural area and their peers from urban schools (especially from elite ones). In the research, mechanisms of reproduction of educational inequality are divided into four dimensions: economic capital of the school, economic capital of the family, cultural capital of the school and cultural capital of the family.

Reproduction of educational inequality through economic capital of the school is represented in such mechanisms as the lack of a mechanism to fully and timely provide schools with necessary teaching materials; the lack of public funding on providing appropriate material and technical bases for studying; the lack of additional sources on improving studying conditions in rural schools. All these obstacles interfere with the learning process and make children from rural schools deprived comparing to their peers from urban area, where studying conditions are better.

The lack of the economic capital of the family influences children's from rural area chances to get higher education through the next mechanisms: the lack of financial opportunities to provide afterschool preparation for the Independent Testing; giving preference to vocational education in order to reduce household expenses on a child and (for those who overcome structural obstacles and passed Independent Testing at least with the minimum passing grade) choosing of less prestigious universities close to the place of residence in order to reduce expenses on bigger tuition fee, transportation and living in a big city.

Cultural capital of the rural schools reproduces inequality in access to higher education through such structural factors as less attention of the teachers on preparation to the External Independent Testing and less amount of time on repetition and generalization comparing to indepth learning in specialized classes of urban schools; the outflow of more successful students to specialized schools in urban area and perceiving of students with high educational performance as outliers, that spoils learning environment in rural schools. 
The specificity of the cultural capital of the family influences children's from rural schools chances to enter university through the next mechanisms: the lack of information about Independent Testing, which produces fear of it; limited parent involvement in educational process and lack of their support in preparation for EIT; the lack of time on preparation to the examinations because of the work on the farm as an important part of daily practice in rural area. As a result, all the structural obstacles affects children's from rural area preparation to the Independent Testing, reducing their chances to get higher education and change their socio-economic positions.
Current educational reforms of secondary and higher education in Ukraine not only won't improve situation with access to higher education for children from poor social background, but also will make it even more limited. Closing of unprofitable universities and schools in rural area, expanding the years of studying at school and implementation on funding reallocation based on a competition with financial support only of those, who are more successful, will deepen educational inequality, making accesses to the mechanism of changing socio-economic position even more dependent from socio-economic background.

\section{References}

1. Bourdieu, P., \& Passeron, J. (1979). The inheritors: French students and their relation to culture. Chicago: University of Chicago Press.

2. Bourdieu, P. (1998). The state nobility: elite schools in the field of power. Stanford University Press.

3. Briginets, M., \& Grushetsky, A. (2010). Comparative analysis of normal and elite schools in Ukraine, Commons Education Policy, 3, 86-96.

4. Devine, F. (2004). Class practices. How parents help their children get good jobs. Cambridge University Press.

5. International Monetary Fund (2015). Ukraine: a letter of intent. Kyiv.

6. Kvit, S. (2015). Changes needed: content and objectives of the educational reform, Ukrainian Pravda. Retrieved from http://www.pravda.com.ua/articles/2015/01/27/7056516/?attempt=1.

7. Kyiv International Institute of Sociology (2013). Dynamics of Internet use in Ukraine. Retrieved from http://www.kiis.com.ua/?Lang=ukr\&cat=reports\&id=199\&page $=1$.

8. Muliavka, V., \& Oksamytna, S. (2015). Educational inequality by type of residence and type of educational institution. Scientific notes of NaUKMA. Sociological Sciences, 174, 9-20.

9. OECD (2016). Country statistical profile: United States 2016. Retrieved from http://www.oecdilibrary.org/economics/country-statistical-profile-united-states_20752288-table-usa\#.

10. Oksamytna, S. (2006). Intergenerational educational mobility in the context of the three age cohorts of the population of modern Ukraine. Scientific notes of NaKUMA, Sociological Sciences, 10, 58-65.

11. Reay, D. (1998). Class work: Mothers' involvement in their children's primary schooling. Taylor \& Francis.

12. The Cabinet of Ministers of Ukraine "On Approval of the State Standard of Full Secondary Education" dated April 20, 2011 № 1392.

13. The Cabinet of Ministers of Ukraine "The draft Law on Amendments to Certain Legislative Acts of Ukraine" dated 15 September, 2016, № 5130 .

14. The World Bank (2015). Gross enrolment ratio, tertiary, both sexes (\%). Retrieved from http://data.worldbank.org/indicator/SE.TER.ENRR.

15. Ukrainian Center for Educational Quality Assessment (2014). Official Report of an external independent testing of educational achievements of persons who wish to enter higher educational institutions of Ukraine in 2014. Retrieved from http://testportal.gov.ua/files/reports/Report2014_Tom_1.pdf. 